\title{
OVARY DEVELOPMENT, FSH AND LH GENES EXPRESSION OF INDONESIAN LEAFFISH, Pristolepis grootii (Bleeker, 1852), INJECTED WITH LUTEINIZING HORMONE-RELEASING HORMONE ANALOG
}

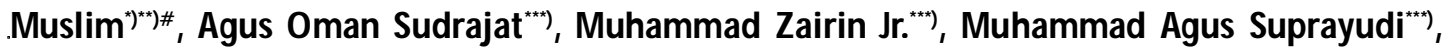

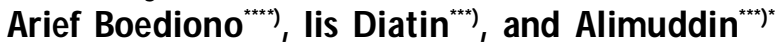 \\ *) Doctoral Program, Postgraduate School, Aquaculture Study Program, IPB University \\ "N Study Program of Aquaculture, Faculty of Agriculture, Sriwijaya University \\ ***) Department of Aquaculture, Faculty of Fisheries and Marine Sciences, IPB University \\ Department of Anatomy, Physiology and Pharmacology, Faculty of Veterinary Medicine, IPB University
}

(Received: June 17, 2021; Final revision: August 24, 2021; Accepted: August 24, 2021)

\begin{abstract}
Indonesian leaffish, Pristolepis grootii (Bleeker, 1852), is an undomesticated freshwater fish species native to the rivers, flooded swamps, and tributaries of Indonesia. The fish is mainly captured for consumption. In order to prevent its extinction and supply its growing demands, the artificial breeding of the fish should be developed. The purpose of this study was to determine the optimum dose of luteinizing hormone-releasing hormone analog (LHRHa) for stimulating the female P. grootii gonadal development at a dosage of $0,1,10$, and $50 \mathrm{\mu g} \mathrm{kg}^{-1}$ of fish. Female fish $(20.0 \pm 0.6 \mathrm{~g})$ were adapted for 30 days in the rearing environment and then separated into 12 aquariums with six fish per aquarium. Fish were then reared for another 21 days and fed with Tubifex sp. The LHRHa injection was conducted twice on day-7 and 14. Fish bodyweight, gonadosomatic index, gonad histology, blood estradiol-17 $\beta$, and FSH- $\beta$ and LH- $\beta$ gene expression were evaluated at day $0,7,14$, and 21 . The results showed that the injection of the LHRHa hormone stimulated the development of fish gonads and was better achieved with a higher concentration of LHRHa. The best treatment was observed by the administration of $50 \mathrm{\mu g} \mathrm{kg}^{-1}$ of LHRHa that produced the fastest development among all treatments. This study demonstrated that the LHRHa induction could potentially stimulate the gonadal development of the newly domesticated fish. To our knowledge, this is the first study that reported the success of the induction of female gonad development in the Indonesian leaffish P. grooti.
\end{abstract}

\section{KEYWORDS: estradiol; gonadotropin; reproduction; Pristolepis}

\section{INTRODUCTION}

Indonesian leaffish, Pristolepis grootii (Bleeker, 1852), is a freshwater fish species that is native to the rivers, flooded swamps, and tributaries of the Indonesian Island of Sumatra, Borneo, and some parts of Malaysia and Thailand (Kottelat et al., 1993; Parenti, 2005). The leaffish are captured by local fisherman mainly for consumption because of their pleasant flavor and thick flesh. Nowadays, the leaffish population begins to decline and is harder to find due to the excessive exploitation, habitat desctruction, and the absence of culture technology of the fish. To prevent its extinction and maintain production, the domestication and artificial breeding of this fish should be conducted.

* Correspondence: Aquaculture Study Program, IPB University E-mail: alimuddin@apps.ipb.ac.id
Wild fish adapted to aquaculture environment tend to experience a reproductive system disturbance, especially for female fish (Zohar \& Mylonas, 2001). It could be caused by different and limitation of the rearing environments (Fobert et al., 2019), nutrient availability (Shiguemoto et al., 2021), egg substrates (Fukuda \& Sunobe, 2017), pheromones, and environmental signals (Sorensen $\&$ Stacey, 2004) compared to its natural habitat. Aside from environmental manipulation, hormonal induction is reported to be the most successful method to stimulate the fish gonadal development for the domesticated fish. Luteinizing begins hormone-releasing hormone and its analog are widely used to stimulate fish gonadal development, referring to its critical role in stimulating the reproduction process cascade (Alcántar-Vázquez et al., 2016; Çek \& Gökçe, 2006; Thomas et al., 2020). 
Fish gonad development could be characterized morphologically and by histology (Feist et al., 2015; Nurhidayat et al., 2017), hormone analysis (NishiwakiOhkawa \& Yoshimura, 2016; Prasad et al., 2015), and genetics (Piferrer et al., 2012). Furthermore, morphological alteration of the gonad may be noticed due to change in shape, size, length, color and fillings of the abdominal cavity (Burns \& Cole, 2017; Zeyl et al., 2014). The gonadal development process is controlled by the endocrine system (Ramezani-Fard et al., 2013).

Successful stimulation of reproduction by hormone analog was reported in other endemic or newly domesticated fish such as in eel Anguilla bicolor (Sudrajat et al., 2014), seurukan fish Osteochilus vittatus (Muchlisin et al., 2014), rice field eel Monopterus albus (Putra et al., 2013), striped snakehead Channa striata (Ath-thar et al., 2017), chocolate go urami Sphaerichthys osphromenoides (Nur et al., 2017), clown knifefish Notopterus chitala (Setijaningsih et al., 2018). This study aimed to determine the doses of LHRHa to induce gonadal development of female Indonesian leaffish (P. grootii).

\section{MATERIALS AND METHODS}

\section{Fish Maintenance and Rearing}

Fish were caught from the Ogan Ilir River, South Sumatera, and transported to Sriwijaya University rearing facility. Female fish were selected by observing the urogenital holes and then sorted by the bodyweight for the experiment. Selected female fish with an average body weight of $20.0 \pm 0.6 \mathrm{~g}(\mathrm{n}=$ 100 ) were adapted in 2,000 L fiberglass tanks with constant aeration for 30 days. During adaptation, the fish were fed with Tubifex sp. ad-libitum (47\%protein, $18.9 \%$ fat, crude fiber $2.7 \%$ NFE $20.5 \%$ and ash $10.8 \%$. During the adaption, the fish responded to the feeding and showed benign behavior, indicating that the fish were successfully adapted in the rearing environment.

After adaptation, fish were reared in 12 aquariums $(60 \mathrm{~cm} \times 40 \mathrm{~cm} \times 40 \mathrm{~cm})$, with six fish in each aquarium. Each aquarium was filled with $30 \mathrm{~L}$ of fresh water and equipped with a constant aeration system. Fish were fed with Tubifex sp. three times a day at apparent satiation in the morning, afternoon, and evening. Waste removal and $10 \%$ water change were conducted by siphoning every two days.

The water of the aquariums was renewed every two days. Water exchange was as much as $10 \%$ of the total volume, using fresh water from a reservoir. Water temperature, dissolved oxygen, and $\mathrm{pH}$ were monitored in-situ daily. Other water variables (ammonia and alkalinity) were checked ex-situ weekly. Water tem- perature ranged from $25.9^{\circ} \mathrm{C}$ to $30^{\circ} \mathrm{C}$ during the experiment, $\mathrm{pH}$ ranged from 5.3 to 6.8 , dissolved oxygen, ammonia, and alkalinity varied between 5.88$7.91 \mathrm{mg} . \mathrm{L}^{-1}, 0.018-0.039 \mathrm{mg} . \mathrm{L}^{-1}, 10-42 \mathrm{mg}^{\mathrm{L}^{-1}}$, respectively.

\section{Hormone Injection}

The LHRHa hormone (Quintrol, Taiwan) was administered by intramuscular injection at different dosages: 0 (P1), 1 (P2), 10 (P3), and 50 (P4) $\mu \mathrm{g} \mathrm{kg}^{-1}$. The injection was performed twice, at day-7 and 14 of rearing. Before injection, the fish were anesthetized with tricaine methane-sulfonate (MS-222) at a dose of $1 \mathrm{~mL}$ per 3 liters of water. The first injection was conducted at the right side of the dorsal and left side for the second injection. After injection, fish were reared for 21 days with the same treatment as previously described.

\section{Fish Sampling}

Fish were randomly sampled at $0,7,14$, and 21 days after hormone injection from each treatment $(n=2)$. Fish were anesthetized, after which the fish's body weight and length were measured. Blood samples were collected from the caudal veins of the sampled fish. Blood was centrifuged for 15 minutes at 3,000 rpm. The supernatant was taken and then stored at $-80^{\circ} \mathrm{C}$ for further analyzes. After blood collection, fish were dissected to obtain the gonad and pituitary. Fish gonad was documented and weighed to measure the gonad-somatic index. Some parts of the gonad were preserved for histological analysis. The pituitary was stored in Genezol ${ }^{\mathrm{TM}}$ reagent (Geneaid, Taiwan) and immediately froze in liquid nitrogen at $-121^{\circ} \mathrm{C}$ for further analyzes.

\section{Measurement of Blood Estradiol-17 $\beta$}

The level of estradiol-17 $\beta$ hormone was measured by a fluorescent-linked fluorescent (ELFA) immunoassay technique using a commercial kit (Vidas ${ }^{\circledR}$ Estradiol II, Biomerieux, USA). Briefly, the Solid Phase Receptacle (SPR $\left.{ }^{\circledR}\right)$ strip serves as the solid phase and the pipetting device for the assay. The sample is placed in a tube containing the conjugate, an estradiol derivative tagged with alkaline phosphatase. The anti-estradiol-specific antibody sites coated on the inner surface of the SPR compete with the estradiol present in the serum and the estradiol derivative in the conjugation. During the washing process, unbound components are removed. The substrate (4Methyl-umbelliferyl phosphate) is cycled in and out of the SPR during the final detection stage. The hydrolysis of this substrate into a fluorescent product is catalyzed by the conjugate enzyme (4-Methylumbelliferone). Sixty minutes after the assay was 
completed, the fluorescence was measured at 450 $\mathrm{nm}$.

\section{Gonad-Somatic Index and Histology}

Quantitative analysis of gonad development of the female P. grootii was analyzed using the gonadosomatic index (GSI). GSI is an index of gonad weight relative to the total fish weight. Histological evaluation of fish gonad was conducted following the method by Montchowui et al. (2012). Briefly, a portion of gonad samples was fixed in Bouin's solution for 24-48 hours. The samples were then dehydrated in a graded series of alcohol baths. After dehydration, the samples were embedded in paraffin and sectioned using a microtome $(8 \mu \mathrm{m})$. The samples were then stained with hematoxylin and eosin staining and observed under a microscope (Olympus, Japan) at $40 \times 10$ magnification.

\section{FSH- $\beta$ and LH- $\beta$ Gene Expression Levels}

Total RNA was extracted from the pituitary using the Genezol ${ }^{T M}$ reagent following the product instruction. The RNA concentration and purity were measured using a spectrophotometer at 260 and $280 \mathrm{~nm}$. The RNA purification and first-strand CDNA synthesis were conducted using the ReverTraAce ${ }^{\circledR}$ qPCR RT kit with gDNA Remover (Toyobo, Japan) from the 20 $n g \mu \mathrm{L}^{-1}$ of total RNA.

The quantitative real-time PCR (qPCR) method was used to compare the gene expression level of FSH- $\beta$ and $\mathrm{LH}-\beta$ between treatments. The qPCR reaction was conducted in Rotor-Gene 6000 machine (Corbett, USA) with the $\beta$-actingene as the calibrator. The amplification was performed using a sensifast SYBR ${ }^{\circ}$ NO-ROX kit (Bioline, UK) with a total of $20 \mu \mathrm{L}$. The qPCR program was optimized in the preliminary study, i.e., pre-denaturation at $95^{\circ} \mathrm{C}$ for two minutes, 40 cycles of amplification for denaturation at $95^{\circ} \mathrm{C}$ for 15 seconds, annealing at $60^{\circ} \mathrm{C}$ for 15 seconds, and extension at $72^{\circ} \mathrm{C}$ for 10 seconds. The qPCR primers were designed based on the FSH- $\beta, \mathrm{LH}-\beta, \beta$-actin mRNA sequence of the Pristolepis fasciata, since the sequence data of $P$. grootii is not available yet in the Genbank. The primers sequence is presented in Table1.

\section{Data and Statistical Analysis}

The gene expression levels were measured using the comparative 2-Ä̈cT method. Gonad morphology and histology were descriptively assessed. Other parameters were analyzed using the IBM SPSS Statistics 25 (IBM, New York, USA) by the analysis of variance (ANOVA) followed by Duncan's test to determine the existence of significant differences between treatments $(p=0.05)$.

\section{RESULTS AND DISCUSSION}

\section{Gonad Development}

The morphology of female fish gonads of $P$. grootii appeared to be elongated and in pairs, located under the swimbladder as commonly found in other teleost fish. The development of P. grootii ovaries after hormonal injection is shown in Figure 1.

Before injection, the gonads were observed to be pink, clear, and deflated in all treatments. At seven days after injection, the control gonad appearance was similar to the original condition, with a slight increase in size. In the hormone treatments, the color was turned to be yellowish at day-7. These variations became more apparent in each treatment until day21 after injection, characterized by an increase in size, darker yellow coloration, better clarity in the covering blood vessels, and firmer and thinner-looking membrane. Thus, a higher dose of LHRHa injection leads to more significant gonad development, shown by the faster development in terms of size and in line with the GSI results in Figure 2.

The GSI index serves as an indicator for maturity development and the reproduction cycle. The GSI of the injected fish increased in line with the elevated dose of LHRHa and was significantly higher than the control since day-7 until the end of the observation $(p<0.05)$. In addition, the highest GSI value was ob-

Table 1. Primer sequences used in the study

\begin{tabular}{ccccc}
\hline Gene & Sequence & Tm ('C) & GC\% & Product length (bp) \\
\hline \multirow{2}{*}{ FSH- $\beta$} & F: 5'-TGGTTGTCATGGCAGCAGTG-3' & 61.17 & 55 & \multirow{2}{*}{278} \\
& R: 5'-GCAGTTTCTGGCCACAGGGTA-3' & 62.61 & 57 & \\
\hline \multirow{2}{*}{ LH- $\beta$} & F: 5'-CTTCCAGCTGCCGCCCTGTCAG-3' & 67.84 & 68.18 & \multirow{2}{*}{297} \\
& R: 5'-AAGGTGCAGTCGGACGTGTCCA-3' & 66.32 & 59.09 & \\
\hline \multirow{2}{*}{$\beta$-actin } & F: 5'-CCTCCTCCCTGGAGAAAAGC-3' & 59.75 & 60 & \multirow{2}{*}{123} \\
& R:5'-TACCGCAGGACTCCATACCA-3' & 60.03 & 55 & \\
\hline
\end{tabular}


PI

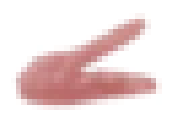

n
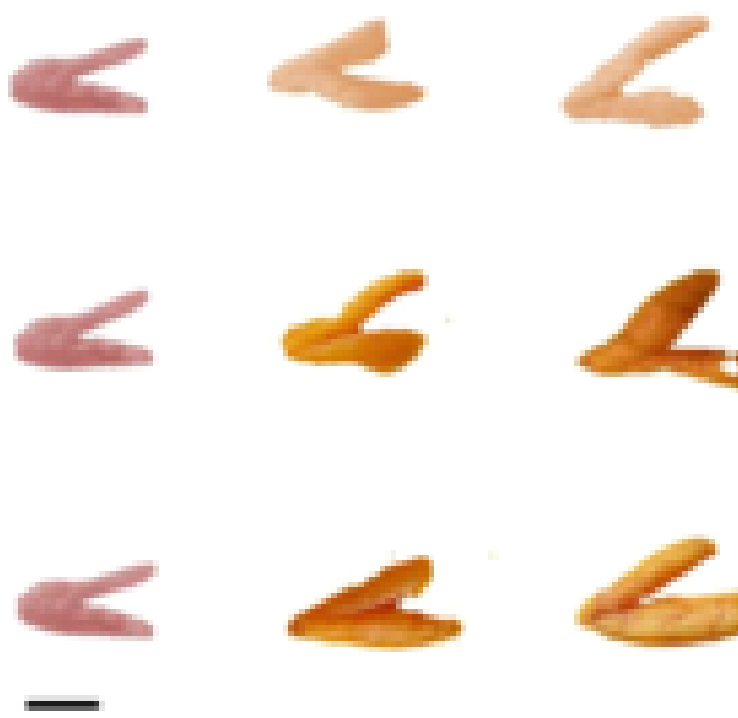

Disin
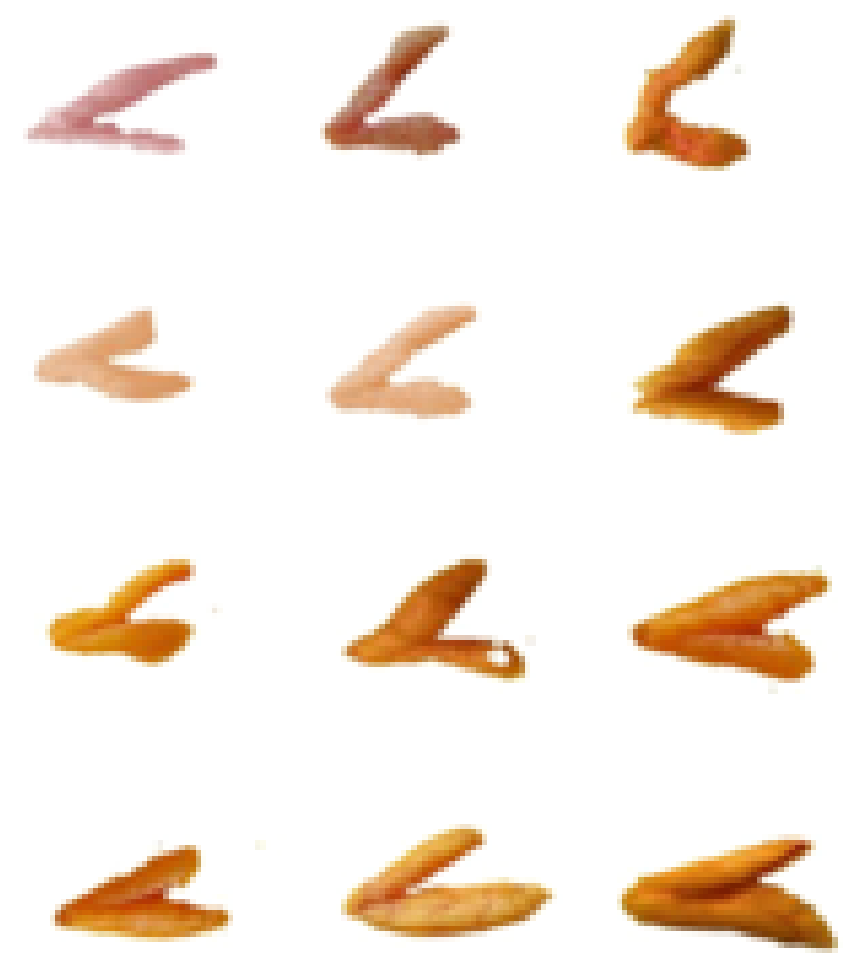

IIIII

\section{IIIII}

Figure 1. Indonesian leaffish (P. grootii) ovarian development after LHRH analog injection with a dosage of $0 \mu \mathrm{g} \mathrm{kg}^{-1}(\mathrm{P} 1), 1 \mu \mathrm{gkg}^{-1}(\mathrm{P} 2), 10 \mu \mathrm{gkg}^{-1}(\mathrm{P} 3)$, and $50 \mu \mathrm{kgg}^{-1}$ (P4). Scale bar represents $1 \mathrm{~cm}$.

tained at the P4 treatment compared to other injection treatments $(p<0.05)$. As shown by the current results, a higher concentration of LHRHa dosage is generally reported to significantly elevate the value of GSI, which further increases the development of the gonad. The increase in gonad size was directly affected the fish body weight. Fish injected with LHRHa had a slightly higher body weight, and fish lengths $(p<0.05)$.

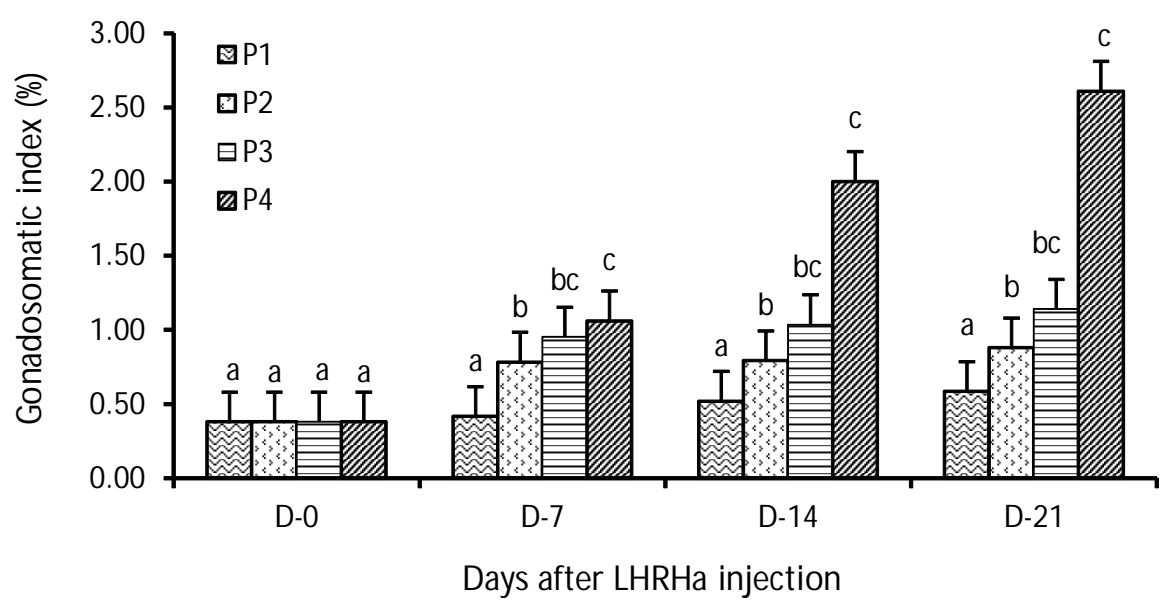

Figure 2. Indonesian leaffish gonadosomatic index (P. grootii) after LHRH analog injection with a dosage of $0 \mu \mathrm{g} \mathrm{kg}^{-1}$ (P1), $1 \mu \mathrm{g} \mathrm{kg}^{-1}$ (P2), 10 $\mu \mathrm{g} \mathrm{kg}^{-1}(\mathrm{P3})$, and $50 \mu \mathrm{g} \mathrm{kg}^{-1}(\mathrm{P} 4)$. Different letters indicate a significant difference between treatments at the same time point. The data is presented as mean $\pm S D(n=3)$. 
An increase in gonad weight is mainly caused by the accumulation of vitellogenin. The increase could be stimulated through hormone manipulation, including the stimulation of gonadotropin hormone (Cao et al., 2014; Mazón et al., 2015).
An increased LHRHa dosage indicates an elevation in the value of GSI, which further increases on gonads development (Bobe et al., 2017). This further serves as an indicator for maturity and reproduction cycle (Jewel et al., 2019; Muddasir \& Neelofar, 2017; Hiramatsu et al., 2015).
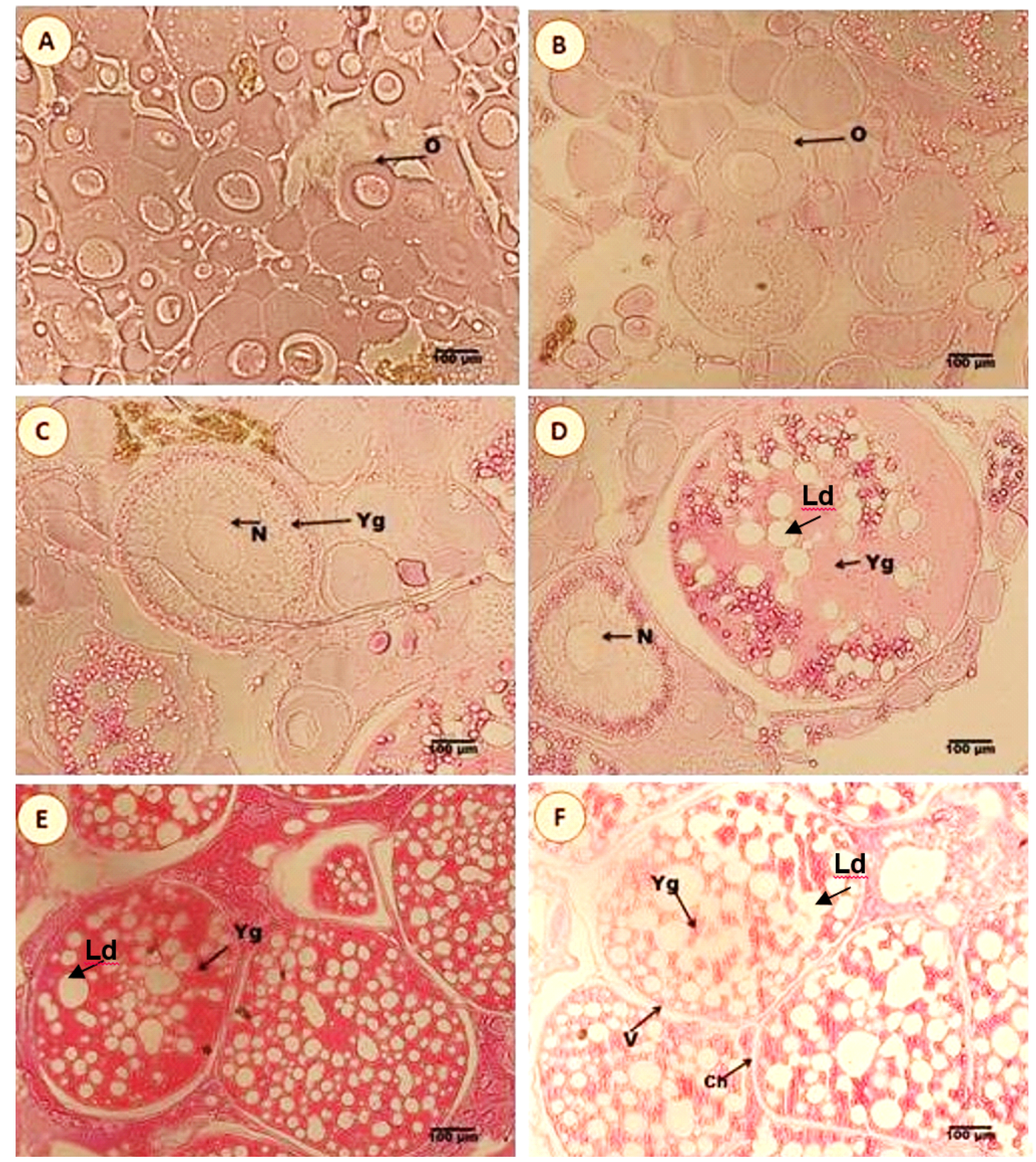

Figure 3. Histological profile of female Indonesian leaffish (P. grootii) ovaries after injected with $50 \mu \mathrm{gkg}^{-1}$ LHRHa. $\mathrm{O}=$ oocyte, $\mathrm{N}=$ nucleus, $\mathrm{Ld}=$ lipid droplets, $\mathrm{Yg}=$ yolk granule, $\mathrm{V}=$ vitelline, $\mathrm{Ch}=$ chorion. Previtellogenesis phase. The oocytes were still in small size without significant development signs at day-0 (A). Vitellogenesis-I phase at day-7 with larger oocyte (B). Vitellogenesis-II phase with a larger nucleus and yolk granules observed (C). In the ovary with the vitellogenesis-III phase, the cells were significantly developed with increased yolk granule accumulation (D). The vitellogenesis-IV phase of ovarian development with more distributed developed cells and lots of lipid droplets were observed on day-14 (E). Ovary with the vitellogenesis-V phase at 21 days after injection, chorion, and vitellin showed significant development and accumulation of yolk granules (F). 
The process of egg and gonad maturation consisted of proliferation, primary and secondary growth, and the maturation phase. Before the injection, primary oocytes were still observed with no yolk granules, indicating that the gonad was in the pre-vitellogenesis phase (Nurhidayat et al., 2017). The previtellogenesis (pre- $\mathrm{Vg}$ ) phase is characterized by oocyte diameter ranging from 50-150 $\mu \mathrm{m}$, dark purple cytoplasm with hematoxylin-eosin staining, and an increase in nucleus diameter and number. Following the induction with LHRHa, the development phase entered vitellogenesis, and a visible yolk granule buildup, which was sustained through vitellogenesis phase I-V (Figure 3A-E). In addition, the oocyte diameter ranged from 160-300 $\mu \mathrm{m}(\mathrm{Vg}-\mathrm{I}), 350-460 \mu \mathrm{m}(\mathrm{Vg}-$ II), 470-580 $\mu \mathrm{m}$ (Vg-III), 600-750 $\mu \mathrm{m}(\mathrm{Vg}-\mathrm{IV})$, and 770 $950 \mu \mathrm{m}(\mathrm{Vg}-\mathrm{V})$. At the end of rearing, the gonad was entered the maturing processes (Figure 3D-E). It was observed to have spherical characteristics at the edge of the cytoplasm with a significant increase in the number and size of egg yolks, and the lipid droplets (Feist et al., 2015; Gardner et al., 2015; Kagawa, 2013; Lubzens et al., 2010). These results indicate that the gonad of the female P. grooti underwent maturing process after LHRHa injection. It is the first study that reported the success of female gonad development induction using the hormonal treatment in $\mathrm{P}$. grooti.

\section{Estradiol-17 $\beta$ Levels}

Blood estradiol-17 $\beta$ levels had increased along with the elevation in LHRHa doses and time, as presented in Figure 4. Therefore, the highest values $(p<0.05)$ are observed in treatment P4 (Figure 4).
The high estradiol concentration in hormone treatment confers the gonad development and GSI. This hormone plays a major role in stimulating the liver to synthesize and secrete vitellogenin, a precursor of egg yolk protein. Circulated estradiol is also captured by receptors in growing oocytes triggering proteolytic division of vitellogenin into sub-units of lipoprotein, lipovitellin, and phosphyitin, thus adding significant progress on the maturing gonad (Sullivan et al., 2018). These results indicated that the LHRHa injection was able to increase the circulated estradiol in the P. grootii blood thus stimulating the reproduction development.

\section{FSH- $\beta$ and LH- $\beta$ mRNA Levels}

LHRHa injection will stimulate the synthesis and secretion of LH as well as FSH in the pituitary. This secretion of $\mathrm{LH}$ and $\mathrm{FSH}$ will functionally regulate the gametogenesis of the fish, including the secretion of estradiol. To confirm the alteration of $\mathrm{LH}$ and FSH after LHRHa injection, the mRNA levels of FSH- $\beta$ and $\mathrm{LH}-\beta$ genes in the fish pituitary were analyzed as the sub-units part of the FSH and LH gene, respectively (Figure 5). FSH is more involved in the initiation of gametogenesis and the subsequent regulation of gonad growth, while LH controls maturation and ovulation or spermiation.

The results showed that the levels of FSH- $\beta$ and LH- $\beta$ expression were not significantly different in all treatments at some points, although there was a tendency of high expression in the higher dose of LHRHa. On day- 14 and 21 after LHRH injection, the FSH- $\beta$ and LH- $\beta$ expression were higher expressed in the

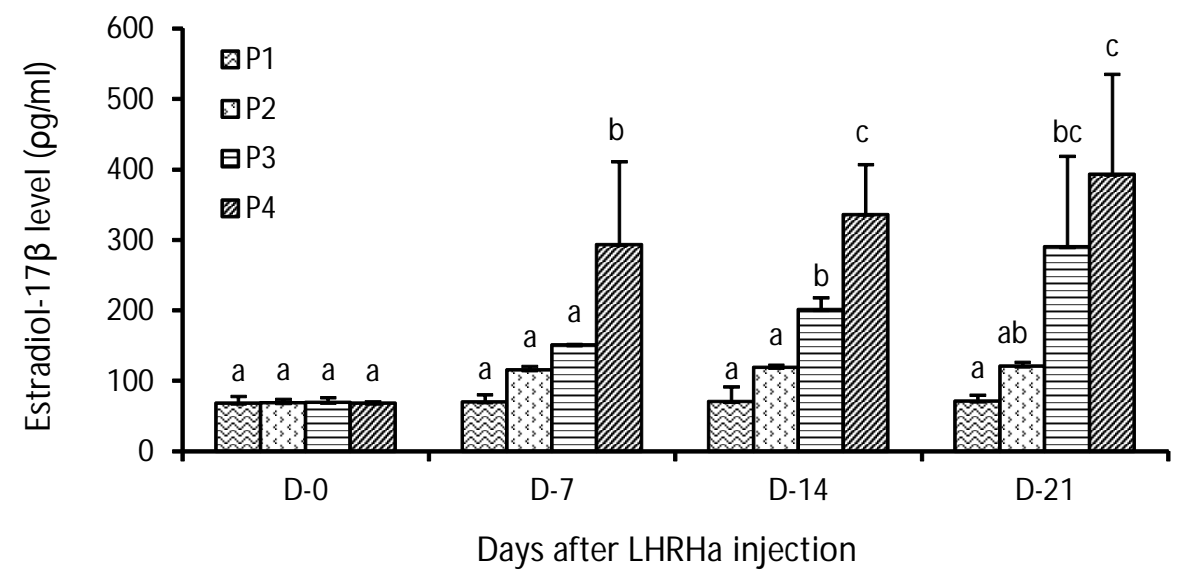

Figure 4. Indonesian leaffish (Pristolepis grootii) estradiol-17 $\beta$ levels after LHRH analog injection with a dosage of $0 \mu \mathrm{g} \mathrm{kg}^{-1}(\mathrm{P} 1), 1 \mu \mathrm{g} \mathrm{kg}{ }^{-1}$ (P2), $10 \mu \mathrm{g} \mathrm{kg}^{-1}$ (P3), and $50 \mu \mathrm{g} \mathrm{kg}^{-1}$ (P4). Different letters indicate a significant difference between treatments at the same time point. The data is presented as mean $\pm \operatorname{SD}(n=3)$. 

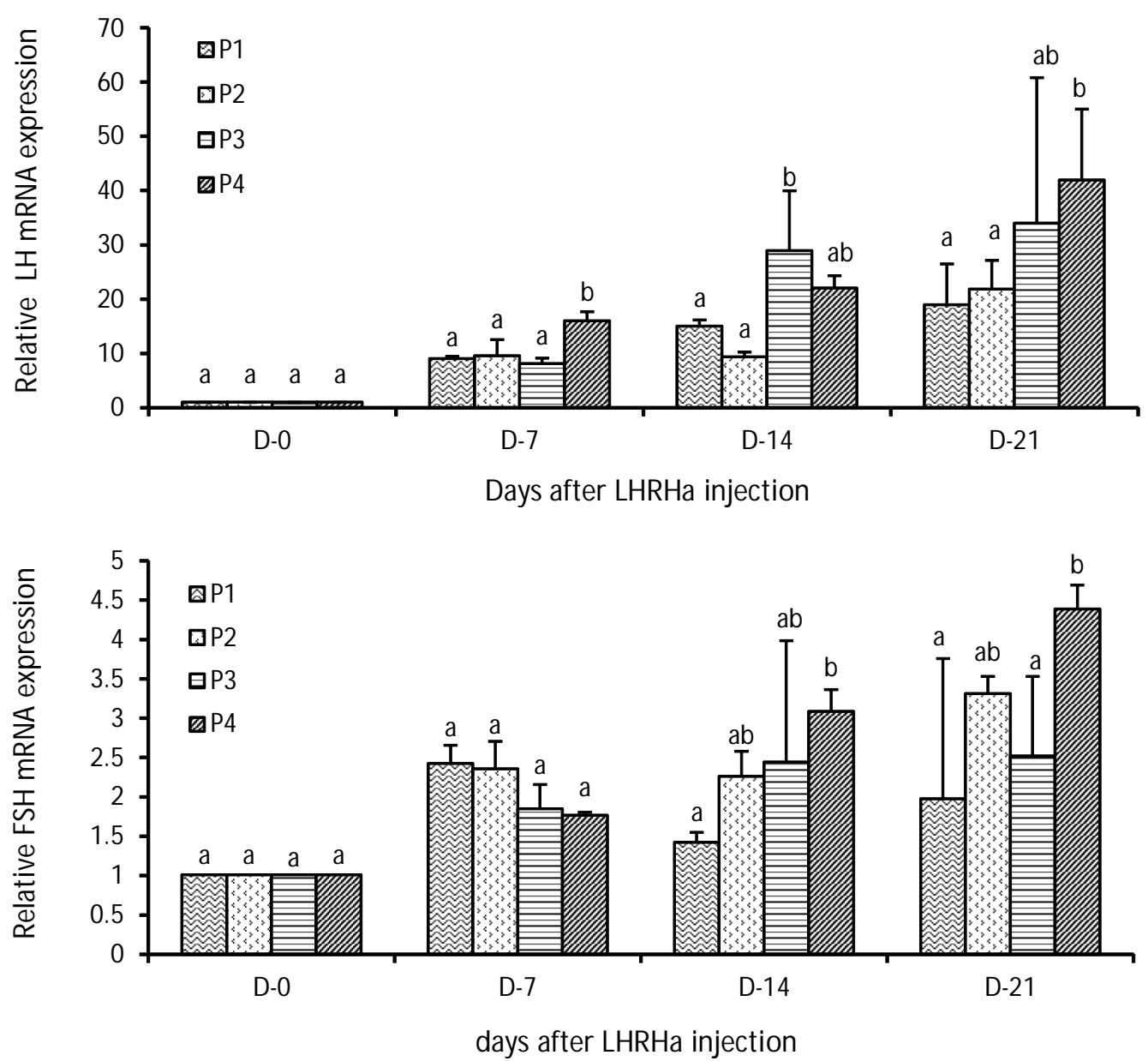

Figure 5. The relative expression of FSH- $\beta$ (top) LH- $\beta$ (bottom) mRNA of Indonesian leaffish (Pristolepis grootii) after LHRH analog injection with a dosage of $0 \mu \mathrm{g}$ $\mathrm{kg}^{-1}(\mathrm{P} 1), 1 \mu \mathrm{g} \mathrm{kg}^{-1}$ (P2), $10 \mu \mathrm{g} \mathrm{kg}^{-1}$ (P3), and $50 \mu \mathrm{g} \mathrm{kg}^{-1}$ (P4). Different letters indicate a significant difference between treatments at the same time point. The data is presented as mean \pm SD $(n=3)$.

LHRHa injection treatment, although not significant. This alteration on day-14 and 21 denotes that gonad development began to reach the final stage of vitellogenesis, shifting towards oocyte maturation. The results showed that the LHRHa injection could upregulate the FSH- $\beta$ and LH- $\beta$ mRNA expression but possessed high biological variation among fish.

\section{CONCLUSION}

The morphological and histological characteristics of the gonads, gonadosomatic index, estradiol-17 $\beta$ levels, and FSH- $\beta$ and $\mathrm{LH}-\beta$ gene expression showed that the injection of the LHRHa hormone stimulated the development of fish gonads. The best treatment in terms of significant gonadal development was observed on administration at a dose of $50 \mathrm{\mu gkg}^{-1}$. A study on ovulation induction of this species is recommended.

\section{ACKNOWLEDGEMENT}

We would like to thank the Ministry of Education and Culture of the Republic of Indonesia, the Education Fund Management Institute (LPDP), the Fisheries Services of Ogan Ilir Regency, South Sumatra Indonesia. Thank you to Dr. Hasan Nasrullah, Mr. Arief Eko Prasetiyo, Ms. Dian Novita Sari, for their assistance and technical help for this study.

\section{REFERENCES}

Alcántar-Vázquez, J.P., Pliego-Cortés, H.S., Dumas, S., Peña-Martínez, R., Rosales-Velázquez, M., \& Pintos-Terán, P. (2016). Effects of a luteinizing hormone-releasing hormone analogue ( $\mathrm{LHRHa}$ ) on the reproductive performance of spotted sand bass Paralabrax maculatofasciatus (Percoidei: Serranidae). Latin American Journal of Aquatic Re- 
search, 44(3), 487-496. doi.org/10.3856/vol44-issue3-fulltext-7.

Ath-thar, M.H.F., Gustiano, R., Kusmini, I.I., Prakoso, V.A., \& Putri, V.P. (2017). Hormonal induction for gonadal maturation of the stripped snakehead, Channa striata. Jurnal Riset Akuakultur, 12(1), 920. doi.org/10.15578/jra.12.1.2017.9-20 (In Indonesian).

Bobe, J., Young, G., Sullivan, C.V., Lubzens, E., Bobe, J., Young, G., \& Sullivan, C.V. (2017). Maternal investment in fish oocytes and eggs: The molecular cargo and its contributions to fertility and early development. Aquaculture, 472, 107-143.

Burns, M.D. \& Cole, K.S. (2017). Reproductive morphology and its application in testing molecular systematic hypotheses in the family Gobiidae (Teleostei, Gobiiformes). Journal of Fish Biology, 91, 1094-1108. doi.org/10.1111/jfb.13403.

Cao, M., Chen, J., Peng, W., Wang, Y., Liao, L., Li, Y., Trudeau, V.L., Zou, Z., \& Hu, W. (2014). Effects of growth hormone over-expression on reproduction in the common carp Cyprinus carpio L. General and Comparative Endocrinology, 195, 47-57. doi.org/10.1016/j.ygcen.2013.10.011.

Çek, Ş. \& Gökçe, M.A. (2006). The effects of [D-Ala6 Pro9 NEt]-LHRHa and LHRHa + pimozide on plasma sex steroid profiles in adult female seabream (Sparus aurata). Pakistan Journal of Biological Sciences, 9(8), 1486-1491. doi.org/10.3923/ pjbs.2006.1486.1491.

Feist, S.W., Stentiford, G.D., Kent, M.L., Ribeiro Santos, A., \& Lorance, P. (2015). Histopathological assessment of liver and gonad pathology in continental slope fish from the northeast Atlantic Ocean. Marine Environmental Research, 106, 42-50 doi.org/10.1016/j.marenvres.2015.02.004.

Fobert, E.K., Da Silva, K.B., \& Swearer, S.E. (2019). Artificial light at night causes reproductive failure in clownfish. Biology Letters, 15(7), 1-5. doi.org/10.1098/rsbl.2019.0272.

Fukuda, K. \& Sunobe, T. (2017). Basic methods for the study of reproductive ecology of fish in aquaria. Journal of Visualized Experiments, 125, 1-11. doi.org/10.3791/55964.

Gardner, P.G., Frazer, T.K., Jacoby, C.A., \& Yanong, R.P.E. (2015). Reproductive biology of invasive lionfish (Pterois spp.). Frontiers in Marine Science, 2, 1-10. doi.org/10.3389/fmars.2015.00007.

Hiramatsu, N., Todo, T., Sullivan, C.V., Schilling, J., Reading, B.J., Matsubara, T., Ryu, Y.W., Mizuta, H.,
Luo, W., Nishimiya, O., Wu, M., Mushirobira, Y., Yilmas, 0., \& Hara, A. (2015). Ovarian yolk formation in fishes: Molecular mechanisms underlying formation of lipid droplets and vitellogenin-derived yolk proteins. General and Comparative Endocrinology, 221, 9-15. doi.org/10.1016/ J.YGCEN.2015.01.025.

Jewel, A.S., Haque, A., Ferdous, M.S., Khatun, M.S., Khanom, D.A., \& Hasan, J. (2019). Gonadosomatic index and fecundity of threatened reba carp, Cirrhinus reba (Hamilton), in the Ganges River (northwest Bangladesh). Fisheries and Aquatic Life, 27, 80-85. doi.org/10.2478/aopf-2019-0009.

Kagawa, H. (2013). Oogenesis in teleost fish. AquaBioScience Monographs, 6(4), 99-127. doi.org/ 10.5047/absm.2013.00604.0099.

Kottelat, M., Whitten, A.J., Kartikasari, S., \& Wirjoatmodjo, S. (1993). Freshwater fishes of western Indonesia and Sulawesi. Periplus Editions, Hong Kong.

Lubzens, E., Young, G., Bobe, J., \& Cerdà, J. (2010). Oogenesis in teleosts: How fish eggs are formed. General and Comparative Endocrinology, 165, 367389. doi.org/10.1016/J.YGCEN.2009.05.022.

Mazón, M.J., Molés, G., Rocha, A., Crespo, B., LanChow-Wing, O., Espigares, F., Munoz, I., Felip, A., Carrillo, M., \& Gómez, A. (2015). Gonadotropins in European sea bass: Endocrine roles and biotechnological applications. General and Comparative Endocrinology, 221, 31-41. doi.org/ 10.1016/j.ygcen.2015.05.002.

Montchowui, E., Compère, P., Thiry, M., Lalèyè, $P_{.}$, Philippart, J., \& Poncin, P. (2012). Histological assessment of gonad maturation in Labeo parvus (Teleostei/ : Cyprinidae) in Benin. African Journal of Aquatic Science, 37(2), 155-163.

Muchlisin, Z.A., Arfandi, G., Adlim, M., Fadli, N., \& Sugianto, S. (2014). Induced spawning of seurukan fish, Osteochilus vittatus (Pisces: Cyprinidae) using ovaprim, oxytocin and chicken pituitary gland extracts. AACL Bioflux, 7(5), 412-418.

Muddasir, J. \& Neelofar, J. (2017). Studies on the fecundity (F), gonadosomatic index (GSI) and hepatosomatic index (HSI) of Salmo trutta fario (Brown trout) at Kokernag trout fish farm, Anantnag, Jammu and Kashmir. International Journal of Fisheries and Aquatic Studies, 5(6), 170173.

Nishiwaki-Ohkawa, T. \& Yoshimura, T. (2016). Molecular basis for regulating seasonal reproduction 
in vertebrates. Journal of Endocrinology, 229, 117127. doi.org/10.1530/J0E-16-0066.

Nur, B., Cindelaras, S., \& Meilisza, N. (2017). Induced maturation of chocolate gourami (Sphaerichthys osphromenoides Canestrini, 1860) using pregnant mare serum gonadotropin (PMSG) and antidopamin hormones. Jurnal Riset Akuakultur, 12(13), 69-76. doi.org/10.15578/jra.12.1.2017.6976.

Nurhidayat, L., Arfiani, F.N., \& Retnoaji, B. (2017). Gonadosomatic index and histological structure of uceng fish gonads (Nemacheilus fasciatus, Valenciennes in Cuvier and Valenciennes, 1846). Biosfera, 34(2), 67-74. doi.org/10.20884/ 1.mib.2017.34.2.456.

Parenti, L. (2005). Fishes of the Rajang Basin, Sarawak, Malaysia. The Raflles Bulletin of Zoology, 13, 175208.

Piferrer, F., Ribas, L., \& Díaz, N. (2012). Genomic approaches to study genetic and environmental influences on fish sex determination and differentiation. Marine Biotechnology, 14, 591-604. doi.org/10.1007/s10126-012-9445-4.

Prasad, P., Ogawa, S., \& Parhar, I.S. (2015). Role of serotonin in fish reproduction. Frontiers in Neuroscience, 9, 1-9. doi.org/10.3389/ fnins.2015.00195.

Putra, W.K.A., Sudrajat, A.O., \& Bambang, N.P. (2013). Induksi maturasi belut sawah (Monopterus albus) dengan hormon human chorionik gonadotropin dan antidopamin. Jurnal Riset Akuakultur, 8(2), 209-220. doi.org/10.15578//ra.8.2.2013.209-220 (In Indonesian).

Ramezani-Fard, E., Kamarudin, M.S., \& Harmin, S.A. (2013). Endocrine control og oogenesis in teleosts. Asian Journal of Animal and Veterinary Advances, 8, 205-215.

Setijaningsih, L., Subagja, J., Radona, D., Pantjara, B., \& Kristanto, A.H. (2018). Performance of clown knifefish Notopterus chitala in natural and artificial spawning conditions. Jurnal Riset Akuakultur, 13(1), 115-122. doi.org/10.15578/ jra.13.2.2018.115-122 (In Indonesian).
Shiguemoto, G.F., Arashiro, D.R., Levy-Pereira, N., Santos, S.C.A., Senhorini, J. A., Monzani, P.S., \& Yasui, G.S. (2021). Domestication strategies for the endangered catfish species Pseudopimelodus mangurus Valenciennes, 1835 (Siluriformes: Pseudopimelodidae). Brazilian Journal of Biology, $81(2)$, 301-308. doi.org/10.1590/15196984.224913.

Sorensen, P.W. \& Stacey, N.E. (2004). Brief review of fish pheromones and discussion of their possible uses in the control of non-indigenous teleost fishes. New Zealand Journal of M arine and Freshwater Research, 38(3), 399-417. doi.org/10.1080/ 00288330.2004 .9517248 .

Sudrajat, A.O., Sugati, A., \& Alimuddin, A. (2014). Induced maturation of eel Anguilla bicolor using different hormone combination. Indonesian Journal of Aquaculture, 12(2), 189-201. doi.org/10.19027/ jai.13.189-201 (In Indonesian).

Sullivan, C.V., Yilmaz, O., Aquagyn, C., States, U., \& Yilmaz, O. (2018). Vitellogenesis and yolk proteins, fish. Reference Module in Life Sciences, 6, 266277. doi.org/10.1016/B978-0-12-809633-8.205670.

Thomas, D., Kailasam, M., Rekha, M.U., Jani Angel, R., Sukumaran, K., Sivaramakrishnan, T., Raja Babu, D., ....., \& Vijayan, K.K. (2020). Captive maturation, breeding and seed production of the brackishwater ornamental fish silver moony, Monodactylus argenteus (Linnaeus, 1758). Aquaculture Research, 51(11), 4713-4723. doi.org/ 10.1111/are.14816.

Zeyl, J.N., Love, O.P., \& Higgs, D.M. (2014). Evaluating gonadosomatic index as an estimator of reproductive condition in the invasive round goby, Neogobius melanostomus. Journal of Great Lakes Research, 40(1), 164-171. doi.org/10.1016/ j.jglr.2013.12.004.

Zohar, Y. \& Mylonas, C.C. (2001). Endocrine manipulations of spawning in cultured fish: From hormones to genes. Aquaculture, 197, 99-136. doi.org/10.1016/S0044-8486(01)00584-1. 